\title{
Implementasi Kerukunan Masyarakat dalam upaya Meminimalisir potensi terjadinya Konflik internal di Kecamatan Donggo Kabupaten Bima
}

\author{
Suherman \\ Email: suherman.mh.mdjafar@gmail.com
}

\begin{abstract}
Abstrak
Adapun yang menjadi tujuan dari penelitian ini adalah: (1) Untuk mengetahui dan mendeskripsikan kondisi kerukunan di daerah sasaran; (2) Untuk mengetahui dan menjelaskan bagaimanakah bentuk kerukunan masyarakat dapat mencegah terjadinya konflik Internal di Kecamatan Donggo Kabupaten Bima Penelitian ini menggunakan metode kualitatif dan analisis deskriptif. Selain itu, penelitian ini merupakan bagian dari kegiatan Partisipatory Action Researche (PAR) Pembentukan Wadah Kerukunan dan Ketahanan Masyarakat Lokal. Sasaran penelitian ini adalah masyarakat/umat beragama di wilayah Kecamatan Donggo, Kabupaten Bima, Provinsi NTB. Pemilihan wilayah ini sebagai sasaran penelitian dikarenakan beberapa faktor. Pertama, wilayah Kecamatan Donggo terpencil di pegunungan dan terpisah oleh teluk dengan Kota Bima; Kedua, menurut Koentjaraningrat sebagaimana dikutip oleh Rahman, etnis Donggo termasuk tipe masyarakat pedesaan dan tidak mengalami gelombang pengaruh kebudayaan luar. Kesimpulan dari penelitian ini adalah Kerukunan di wilayah Kecamatan Donggo cukup baik. Meski di wilayah ini terdapat tiga kelompok penganut agama tetapi mereka dapat hidup berdampingan secara damai. Konflik yang pernah terjadi berupa: konflik vertical, horizontal dan dan potensi konflik pun dapat terminimalisir beerkat upaya dan kiat serta peran serta seluruh element yang ada di Kecamatan Donggo.
\end{abstract}

Kata Kunci: Pelaksanaan Kerukunan, Potensi Konflik, Kecamatan Donggo

Abstract

The objectives of this research are: (1) To find out and describe the condition of harmony in the target area; (2) To find out and explain how the form of community harmony can prevent internal conflicts in Donggo District, Bima Regency. This study uses qualitative methods and descriptive analysis. In addition, this research is part of the activities of the Participatory Action Research (PAR) Formation of Local Community Harmony and Resilience. The target of this research is the community / religious community in the Donggo District area, Bima Regency, NTB Province. The selection of this region as a research target is due to several factors. First, the Donggo District area is remote in the mountains and separated by the bay from the City of Bima; Secondly, according to Koentjaraningrat as quoted by Rahman, the Donggo ethnic group is a type of rural community and does not experience a wave of outside cultural influences. The conclusion of this research is that harmony in the Donggo District area is quite good. Although in this area there are three groups of religious adherents, but they can live side by side peacefully. Conflicts that have occurred in the form of: vertical, horizontal and potential conflicts can also be minimized thanks to the efforts and tips as well as the participation of all elements in Donggo District

Keywords: Implementation of Harmony, Potential Conflicts, Donggo District

\section{PENDAHULUAN}

Tatanan-tatanan hukum telah ada di Indonesia jauh sebelum masyarakat mengenal hukum modern. Masyarakat Indonesia telah hidup dengan aturan dan kebiasaan yang bersumber dari masyarakat ini selama beratus- 
ratus tahun yang lalu. Walaupun aturan-aturan hukum tidak berbentuk perundang-undangan yang kita kenal sekarang dengan segala ketentuan dan sanksi yang jelas dan tegas, tetapi tatanan hukum tersebut telah dapat memelihara keteraturan dan melindungi kepentingan masyarakat. Setiap kejahatan yang timbul dalam masyarakat dapat mengganggu keseimbangan tatanan masyarakat. Oleh karena itu, perlu diupayakan agar setiap kejahatan dapat diselesaikan agar keseimbangan tatanan masyarakat dapat dipulihkan. (Sudarto, 1997).

Suku Donggo tinggal di Kecamatan Donggo, Kabupaten Bima, Propinsi Nusa Tenggara Bara (NTB). Nama Donggo atau lengkapnya Dou Donggo berarti "Orang Gunung." berdasarkan lokasinya suku Donggo dibedakan atas Donggo Ipa (Donggo bagian utara) menempati wilayah Desa Kala, O'o, Mbawa, Padende, Kananta, Doridungga, dan Rora, sedangkan Donggo Ele (Donggo bagian timur) menempati wilayah Desa Taralawi, Kuta, Sambori, Teta, Kalodu. Daerah Donggo Ipa terletak disebelah Timur teluk Bima. Donggo Ele terletak disebelah Barat teluk Bima. Perkampungan mereka mengelompok dipinggir jalan atau sungai. Bahasa yang mereka gunakan adalah bahasa Bima Donggo. Dalam bahasa ini ada bahasa halus dan kasar.

Masyarakat Donggo dikenal memiliki kearifan lokal dalam berbagai bidang kehidupan, dalam pembangunan rumah. Kearifan lokal tersebut kini banyak yang hilang, seperti Uma Leme (rumah runcing) yang banyak dikenal di Mbawa dan Padende, yang ukurannya segi empat sama sisi dan bentuknya runcing mirip pucuk gunung yang berbentuk limas atapnya terbuat dari alang-alang yang dirajut tebal, rumah ini merupakan rumah pertama yang dibangun oleh masyarakat Donggo. Dengan hilangnya uma leme ini munculah rumah kedua yang disebut uma jompa (rumah jompa) yaitu rumah yang bentuknya segi empat sama sisi yang pucuknya tidak runcing seperti uma leme tetapi bentuk atapnya seperti rumah panggung biasa. Yang terakhir rumah panggung yang hingga sampai sekarang masih terlihat di Donggo. Sedangkan sosial budaya dalam bertani masyarakat Donggo mengenal kegiatan gotong royong (Hamzah, 2004). Kehidupan masyarakat Donggo memiliki beragam ciri khas baik dibidang, sosial kemasyarakatan, budaya, pertanian dan pernikahan. Salah satu ciri khas kehidupan sosial masyarakat Donggo dalam bidang pernikahan yaitu peristiwa sodi angi dan cepe kanefe (bertunangan dan tukar seperangkat pakaian bayi) bagi masyarakat Donggo bukanlah hal yang baru melainkan telah mentradisi dan mengakar di masyarakat Donggo yang menjadi ciri khas pola kehidupan sosial manyarakat Donggo dalam bidang pernikahan. Cepe kanefe biasanya dilakukan antara wae dengan wae (antara kedua orang tua pria dan wanita) yang sebelumnya diawali dengan kataki angi (menjodohkan) yang kemudian dituangkan dengan sodi angi (bertunangan). Dari peristiwa cepe kanefe tadi melahirkan konsensus hubungan baik antara wae dengan wae dan keluarganya untuk menjalin ikatan lahir sampai kapan putra-putri dijodohkan tadi akan dinikahkannya (Ama la nora, 2008).

Setiap kelompok masyarakat yang menempati wilayah tertentu sebelum adanya ketentuan perundang-undangan sebagaimana yang dibuat oleh Negara, sudah mempunyai cara tersendiri untuk mengatur agar kehidupan individu-individu di dalam kelompok tersebut berjalan tertib dan teratur. Cara-cara tersebut muncul dari nilai-nilai pengalaman dan kebiasaan-kebiasaan yang sering dikenal dengan adat istiadat. Hukum adat berurat dan berakar pada kebudayaan tradisional yang hidup dari perwujudan perasaan hukum yang nyata dari masyarakat dan terus menerus dalam keadaan tumbuh dan berkembang seperti hidup itu sendiri

Sudah lebih dari satu dasawarsa kondisi bangsa Indonesia tidak pernah berhenti dilanda konflik. Jika kita flashback ke belakang, bangsa Indonesia sudah relatif lama berupaya menciptakan kerukunan antarumat beragama dan telah mengalami proses panjang. Sejak tahun 1966 telah dirintis pertemuan antar tokoh agama paska berbagai kerusuhan yang bernuansa SARA, terutama berkaitan dengan perusakan rumah ibadat di berbagai tempat di Indonesia. 
Banyak hal yang telah dilakukan oleh pemerintah bersama tokoh lintas agama mengolah berbagai kebijakan pemerintah dan dibantu datanya oleh Badan Litbang Agama. Kemudian muncul berbagai peraturan Menteri Agama, peraturan bersama dan seterusnya sebagai wujud kebersamaan dari pemerintah dengan Pengembangan Wadah Kerukunan dan Ketahanan Masyarakat Lokal di Kecamatan Donggo.

Para tokoh lintas agama untuk bersamasama mewujudkan kerukunan beragama yang menjamin perdamaian. Pada tanggal 30 Juni 1980, berdasarkan Surat Keputusan Menteri Agama Nomor 35 tahun 1980 dibentuk Wadah Musyawarah Antar Umat Beragama (WMAUB). Wadah tersebut berfungsi sebagai:

1) Forum untuk membicarakan tanggung jawab bersama dan kerja sama antarwarga negara yang menganut berbagai agama;

2) Forum untuk Membicarakan kerja sama dengan pemerintah. Dalam konsideran Surat Keputusan Menteri Agama itu dijelaskan tujuan dari WMAUB adalah: Untuk meningkatkan pembinaan kerukunan hidup di antara sesama umat beragama demi terciptanya kesatuan dan persatuan bangsa (Tim Peneliti Puslitbang Kehidupan Keagamaan, 2007: 1-2).

Pada era reformasi, dalam upaya mengantisipasi/mencegah meluasnya konflik, di berbagai daerah terutama di zona-zona damai, secara bottom-up telah dibentuk berbagai wadah (forum) kerukunan antar umat beragama. Di Sumatera Utara dibentuk FKAPA atau Forum Komunikasi Antar Pemuka Agama (Kustini, 2007: 49-50), di Sulawesi Utara terdapat Badan Kerja Sama Antar Umat Beragama (BKSAUA), dan di kecamatan-kecamatan di berbagai daerah dibentuk Forum Kerukunan Antar Umat Beragama (FKAUB) antara lain, di Buleleng Bali (Ibid), Pahandut Kalimantan Tengah (Ahmad, 2007: 131), Mandonga Sulawesi Tenggara (Hakim, 2007: 428) dan lain-lain. Setelah lahirnya Peraturan Bersama Menteri Agama dan Menteri Dalam Negeri (PBM) Nomor 9 dan 8
Tahun 2006, FKUB atau forum-forum kerukunan sejenis yang sudah dibentuk di provinsi dan kabupaten/kota disesuaikan paling lambat satu tahun sejak PBM ditetapkan 21 Maret 2006 (Badan Litbang dan Diklat Kementerian Agama RI, 2010: 6; Lihat PBM Nomor 9 dan 8 Bab IX, Pasal 27 Ayat 2). Belakangan ini, meskipun pada umumnya forum-forum tersebut telah menyesuaikan dengan FKUB, namun di beberapa daerah, forum-forum kerukunan yang sudah dibentuk lebih dulu termasuk forum-forum kerukunan di tingkat kecamatan masih ada yang dipertahankan kelangsungannya. Keberadaan FKUB maupun forum sejenis di tingkat kecamatan tidak bertentangan dengan PBM, karena FKUB dapat dibentuk di tingkat kecamatan dan kelurahan/desa untuk kepentingan dinamisasi kerukunan, tetapi tidak

memiliki tugas formal sebagaimana FKUB tingkat provinsi dan kabupaten/ kota (Tanya Jawab PBM Bab III, Poin 3). Keberadaan FKUB atau forum sejenis di tingkat kecamatan di beberapa daerah sangat diharapkan oleh para tokoh agama, dengan alasan karena pada umumnya kasus/persoalan terjadi di tingkat kelurahan/kecamatan, sementara FKUB berada di tingkat kabupaten/kota (Ahmad, 2012: 207).

\section{Rumusan Permasalahan}

Dari latar belakang masalah di atas dapat dirumuskan permasalahan penelitian sebagai berikut:

(1) Bagaimana kondisi kerukunan di daerah sasaran;

(2) Bagaimana masyarakat menyadari adanya potensi konflik di wilayahnya dan berupaya untuk mengatasinya;

Adapun yang menjadi tujuan dari penelitian ini adalah: (1) Untuk mengetahui dan mendeskripsikan kondisi kerukunan di daerah sasaran; (2) Untuk mengetahui dan mendeskripsikan potensi konflik dan upaya untuk mengatasinya; (3) Untuk mengetahui dan mendeskripsikan bagaimana masyarakat menggunakan kearifan local (pengembangan wadah kerukunan dan ketahanan masyarakat local) sebagai upaya mempertahankan kerukunan, mengantisipasi dan mengatasi 
konflik. Hasil penelitian diharapkan dapat bermanfaat, Pertama sebagai bahan masukan bagi para pengambil kebijakan dalam upaya pemeliharaan kerukunan; Kedua bagi peningkatan peran masyarakat dalam pemeliharaan kerukunan melalui revitalisasi kearifan lokal.

\section{METODE}

Penelitian ini bersifat studi kasus dengan menggunakan metode kualitatif dan analisis deskriptif. Selain itu, penelitian ini merupakan bagian dari kegiatan Partisipatory Action Researche (PAR) Pembentukan Wadah Kerukunan dan Ketahanan Masyarakat Lokal. Sasaran penelitian ini adalah masyarakat/umat beragama di wilayah Kecamatan Donggo, Kabupaten Bima, Provinsi NTB. Pemilihan wilayah ini sebagai sasaran penelitian dikarenakan beberapa faktor. Pertama, wilayah Kecamatan Donggo

terpencil di pegunungan dan terpisah oleh teluk dengan Kota Bima; Kedua, menurut Koentjaraningrat sebagaimana dikutip oleh Rahman, etnis Donggo termasuk tipe masyarakat pedesaan dan tidak mengalami gelombang pengaruh kebudayaan luar (Rahman dan Nurmukminah, 2011: 38-39). Teknik pengumpulan data yang digunakan adalah: wawancara, pengamatan, studi dokumentasi/kepustakaan dan focus group discussion (FGD). Yang disebut terakhir ini, selain sebagai teknik pengumpulan data juga difungsikan sebagai upaya check and recheck untuk validasi data.

\section{HASIL DAN PEMBAHASAN}

\section{Sejarah Asal Usul Masyarakat Donggo}

Kecamatan Donggo merupakan salah satu kecamatan yang berada dalam wilayah Kabupaten Bima Provinsi NTB yang terletak di dataran tinggi Gunung Lambitu. Wilayah Kecamatan Donggo dibatasi oleh Kecamatan Soromandi di sebelah utara dan timur; Kecamatan Dompu di sebelah barat; dan Kecamatan Madapangga dan Kecamatan Bolo di sebelah selatan. Kecamatan Donggo terdiri dari sembilan desa, yaitu: Desa Oo, Kala, Dori Dungga, Mpili, Mbawa, Palama, Bumi Pajo, Rora, dan Ndano Nae.

Secara historis orang Bima atau Dou Mbojo dibagi dalam dua kelompok, yaitu kelompok penduduk asli yang disebut Dou Donggo yang menghuni kawasan bagian barat teluk, tersebar di gunung dan lembah. Sedangkan Kelompok kedua yang lazim disebut orang Bima atau Dou Mbojo menghuni kawasan pesisir pantai dan merupakan suatu ras bangsa campuran dengan orang Bugis-Makasar dengan ciri rambut lurus sebagai orang Melayu di pesisir pantai (Humas Dompu, 2015).

Dari penelitian Zollinger (1847) berpendapat bahwa Dou Donggo (Donggo di) dan penduduk Bima di sebelah Timur laut teluk Bima (Dou Donggo ele) menunjukkan karakteristik yang jelas sebagai ras bangsa yang lebih rendah, kecuali beberapa corak yang menunjukkan kesamaan dengan orang-orang Bima di sebelah Timur Teluk Bima.

Sedangkan penelitian Elber Johannes (19091910) menyimpulkan pada dasarnya orang Bima yang tinggal disekitar ibukota ada ras bangsa yang lebih tinggi, hidup pula ras bangsa campuran yang bertalian dengan orang Bugis dan Makasar yaitu ras bangsa Melayu muda. Penelitian terhadap anggota masyarakat Bima yang lebih tua menunjukkan suatu kecenderungan persamaan dengan orang sasak Bayan di Lombok. Orang Donggo dan Sasak Bayan memiliki kesamaan ciri yaitu berambut pendek bergelombang, keriting, dan warna kulit agak gelap.

Ras bangsa dan bahasa menurut sejarah perkembangannya, bahasa Bima dibagi dalam dua kelompok yaitu.

1. Kelompok bahasa Bima lama, meliputi: Bahasa Donggo, dipergunakan oleh masyarakat Donggo Ipa yang bermukim di pegunungan sebelah barat teluk meliputi Desa Kala, Mbawa, Padende, Kananta, Doridungga Bahasa Tarlawi dipergunakan oleh masyarakat Donggo ele yang bermukim di pergunungan Wawo Tengah, meliputi Desa Tarlawi, Kuta, Sambori, 
Teta, Kalodu. Bahasa Kolo dipergunakan oleh masyarakat yang bermukim di desa Kolo di sebelah timur Asa kota.

2. Kelompok bahasa Bima baru, lazim disebut nggahi Mbojo. Bahasa Bima baru atau nggahi Mbojo dipergunakan oleh masyarakat umum di Bima dan berfungsi sebagai bahasa ibu. Bagi masyarakat Bima lama, bahasa Bima berfungsi sebagai bahasa pengantar guna berkomunikasi dengan orang lain diluar kalangan mereka.

Jumlah Penduduk Kecamatan Donggo dilihat dari setiap desa dapat dibaca pada tabel 1 berikut:

Tabel: 1. Jumlah Penduduk Setiap Desa di Kecamatan Donggo

\begin{tabular}{|c|c|c|}
\hline No & Nama Desa & Jumlah Penduduk \\
\hline 1 & O'o & 3.480 \\
\hline 2 & Kala & 1.391 \\
\hline 3 & Dori Dungga & 2.929 \\
\hline 4 & Mpili & 1.724 \\
\hline 5 & Mbawa & 4.616 \\
\hline 6 & Palama & 1.517 \\
\hline 7 & Bumi Pajo & 1.798 \\
\hline 8 & Rora & $\begin{array}{c}2.937 \text { (sebelum } \\
\text { pemekaran) }\end{array}$ \\
\hline 9 & Ndano Nae & 20.392 \\
\hline \multicolumn{2}{|c|}{ Jumlah } & \\
\hline
\end{tabular}

Penduduk Kecamatan Donggo sebagaian besar adalah penduduk asli, yakni etnis Donggo (Rahman 2011: 11). Etnis lain yang ada di wilayah ini jumlahnya sangat kecil. Mereka adalah para pendatang yang bertugas sebagai pegawai negeri dan para misionaris/zending. Sangat kecilnya jumlah etnis lain ini dikarenakan wilayah Kecamatan Donggo terpencil di pegunungan dan terpisahkan oleh teluk Bima dengan Kota Bima. Etnis Donggo mendiami lereng Gunung Wawo dan Lambitu yang disebut sebagai Dou Donggo Ele. Sebagian yang lain mendiami lereng Gunung Soromandi setelah pemekaran masuk wilayah Kecamatan Soromandi yang dikenal dengan sebutan Dou Donggo Ipa (Rahman dan Nurmukminah, 2011:
38). Dalam keagamaan, etnis Donggo sangat patuh, tetapi karena mereka tinggal di wilayah yang terpencil di daerah pegunungan menyebabkan mereka sering mencampuradukkan ajaran Islam dengan ajaran pra Islam (Ibid: 39). Jumlah penganut agama di Kecamatan Donggo per desa dapat dilihat pada tabel 2 berikut:

Tabel: 2. Jumlah Penganut Agama di Setiap Desa Di Kecamatan Donggo

\begin{tabular}{|c|c|c|c|c|}
\hline \multirow{2}{*}{ No } & \multirow{2}{*}{ Nama Desa } & \multicolumn{3}{|c|}{ Agama } \\
\hline & & Islam & Katolik & Kristen \\
\hline 1 & O'o & 3.480 & & \\
\hline 2 & Kala & 1.391 & & \\
\hline 3 & Dori Dungga & 2.929 & & \\
\hline 4 & Mpili & 1.724 & & \\
\hline 5 & Mbawa & 3.571 & 934 & 111 \\
\hline 6 & Palama & 1.279 & 110 & 128 \\
\hline 7 & Bumi Pajo & 1.798 & & \\
\hline 8 & Rora & \multirow{2}{*}{20.392} & & \\
\hline 9 & Ndano Nae & & & \\
\hline & Jumlah & 19.109 & 1044 & 188 \\
\hline
\end{tabular}

Jumlah rumah ibadat dan rasionya dengan jumlah engnut di Kecamatan Donggo per desa dapat disimak pada tabel 3 berikut:

Tabel 3. Jumlah Rumah Ibadah dan Rasionya dengan Jumlah Penganut Dilihat Perdesa di Kecamatan Donggo

\begin{tabular}{|c|c|c|c|c|c|}
\hline No & $\begin{array}{c}\text { Nama } \\
\text { Desa }\end{array}$ & Masjid & Mushala & $\begin{array}{c}\text { Gereja } \\
\text { Katolik }\end{array}$ & $\begin{array}{c}\text { Gereja } \\
\text { Kristen }\end{array}$ \\
\hline 1 & O'o & $\begin{array}{c}3 \\
(3 / 2.690)\end{array}$ & 5 & & \\
\hline 2 & Kala & 3 & 4 & & \\
\hline 3 & $\begin{array}{c}\text { Dori } \\
\text { Dungga }\end{array}$ & 3 & 7 & & \\
\hline 4 & Mpili & 3 & 2 & & \\
\hline 5 & Mbawa & 3 & 5 & 2 & $1(1 / 82)$ \\
\hline 6 & Palama & 2 & 1 & $1(1 / 80)$ & \\
\hline 7 & Bumi Pajo & 2 & 2 & & \\
\hline 8 & Rora & $2 / 1$ & $3 / 1$ & & $1(1 / 82)$ \\
\hline \multicolumn{7}{|c|}{ Jumlah } & $22(1 / 756)$ & 30 & $\begin{array}{c}3 \\
(1 / 318)\end{array}$ & $1(1 / 86)$ \\
\hline
\end{tabular}

Jumlah rumah ibadah tersebut, bagi umat Islam dengan asumsi umat Muslim melakukan shalat Jumat hanya di masjid, dan jumlah lelaki dewasa $1 / 3$ dari jumlah penduduk maka jumlah 
rumah ibadah tersebut secara umum dapat dikatakan cukup memadai. Hanya Desa Oo, dengan rasio 1 masjid untuk 1.690 umat atau 1 masjid untuk 563 penduduk lelaki Muslim dewasa, yang perlu perluasan masjid atau penambahan jumlah masjid. Karena untuk ukuran masjid di desa dengan kapasitas di atas 500 orang memang sangat langka. Meski umat Muslim bisa melakukan shalat Jumat di masjid yang kapasitasnya kurang memadai, karena jamaah bisa melakukan shalat di halaman masjid bahkan sampai luber ke jalanan. Sedangkan untuk umat Kristen dengan rasio 1 gereja untuk 82 umat dapat dikatakan cukup memadai. Sedangkan untuk umat Katolik khususnya di Desa Mbawa dengan rasio 1 gereja untuk 874 umat dapat dikatakan kurang memadai. Sehingga perlu perluasan bangunan atau penambahan jumlah gereja. Meski peribadatan umat Katolik dapat dilakukan dengan cara sif. Jumlah penyuluh agama Islam di Kecamatan Donggo sebanyak 9 orang penyuluh honorer yang berada di setiap desa dan penyuluh PNS satu orang. Jumlah lembaga pendidikan Islam, MIN 2, MTsN 2, sedangkan jumlah sekolah umum, SDN 21, SMP 9, SMA 1 dan SMK 2. Keberadaan lembaga-lembaga pendidikan baik umum maupun agama ini cukup memberikan perubahan yang signifikan bagi kemajuan generasi muda Donggo. Dahulu taraf kehidupan masyarakat Donggo masih terbilang rendah jika dibandingkan dengan etnis-etnis lain. Dalam pendidikan masih belum maju, banyak anak-anak yang belum mengenyam pendidikan. Kehidupan mereka jarang tersentuh pengaruh luar, sehingga lambat untuk menerima perubahan (Ibid: 38). Menurut oentjaraningrat sebagaimana dikutip oleh Rahman, etnis Donggo termasuk tipe masyarakat pedesaan dan tidak mengalami gelombang pengaruh kebudayaan luar (Ibid: 3839). Namun saat ini masyarakat Donggo sudah jauh lebih maju, terutama dalam pendidikan. Meski mereka masih banyak yang tinggal di rumah panggung dengan ukuran yang relatif kecil, tetapi hampir setiap keluarga memiliki anggota keluarga yang telah menyandang titel sarjana. Mata pencaharain penduduk Kecamatan
Donggo mayoritas (sekitar 95\%) sebagai petani dan sekaligus sebagai peternak. Hanya sebagian kecil di antara mereka yang menjadi guru (PNS) atau sebagai pedagang. Petani di Donggo hanya mengandalkan curah hujan (petani tadah hujan), karena irigasi di kecamatan ini belum tertata dengan baik di samping karena langkanya sumber air. Oleh karena itu mereka hanya bisa menanam padi atau palawija sekali setahun. Untuk penanaman padi, mereka sering kali mengalami gagal panen (puso) karena pada waktu tanaman padi mulai berbunga sudah tidak turun hujan dan mengalami kekeringan. Selain menanam padi, petani di Kecamatan Donggo juga menanam jagung, kedelai, dan tanaman keras seperti jambu mede, kemiri, cengkeh, coklat dan kopi. Selain Tanaman tersebut terdapat tanaman keras untuk bahan bangunan, seperti jati dan tanaman bahan angunan lainnya. Sebagai usaha sampingan, mereka juga berternak sapi, kerbau, kambing, dan kuda. Dilihat dari sisi ekonomi, penduduk Kecamatan Donggo tergolong miskin. Untuk meningkatkan penghasilan atau perbaikan nasib, sebagian pemuda Donggo mengadu nasib ke negeri Jiran untuk mengais ringgit. Hal ini bias diketahui dari hasil wawancara dengan Bapak Nurdin dari Sangari (Mbawa).

\section{Potensi Ekonomi}

Kerukunan keagamaan adalah sebuah kondisi yang dinamis, selalu on going process dan selalu berubah di setiap saat. Kondisi kerukunan tergantung bagaimana lingkungan strategis di sekitarnya. Di antara lingkungan strategis yang secara teoritik sangat berpengaruh adalah lingkungan social keagamaan, ekonomi, politik, dan keamanan (Tholhah, 2013: xiii-xiv). Tidak jarang akar permasalah konflik SARA yang terjadi di negeri ini bersumber dari masalah kemiskinan dan perebutan sumber daya ekonomi. Oleh karena itu, potensi ekonomi perlu dikemukakan untuk melihat potensi konflik secara sistemik. Kecamatan Donggo memiliki potensi ekonomi yang prospektif, antara lain:

1) Susu kuda liar, yang merupakan produk khas Kabupaten Bima yang cukup terkenal hingga tingkat nasional sebagai obat penyakit 
leukemia (kanker darah). Namun kuda perah di Donggo belum dibudidayakan secara maksimal, sehingga produk susunya masih sangat terbatas.

2) Lebah madu, juga merupakan produk andalan dari Kabupaten Bima. Madu lebah dari Bima dahulu terkenal kualitasnya. Namun masyarakat Donggo belum ada yang membudidayakan lebah madu. Produk madu masih mengandalkan perburuan sarang lebah di hutan. Untuk memenuhi kebutuhan pasar akhirnya pedagang madu memproduksi madu buatan atau mengoplos madu dengan air gula.

3) Perikanan yakni bandeng dan kerang mutiara.

4) Pertambangan berupa emas, pasir besi dan batu bara

5) Hasil Hutan yaitu kayu jati dan cendana/gaharu (Wawancara dengan Bapak Mahyudin, S.Pd.Ek, Kepala Sekolah SDN Palama, Donggo, 19 Agustus 2019).

6) Pariwisata, antara lain:

a. Pacuan kuda yang merupakan atraksi rutin di Kabupaten Bima.

b. Peninggalan purbakala batu tulis dan peninggalan dari jaman Megalitikum, ada yang menyebut sebagai peninggalan Patih Gajah Mada yang situsnya terdapat di Desa Bumi Pajo (Wawancara dengan Makarau, S.Pd.,M.Si tertanggal, 28 Juli 2019 ,

c. Uma leme 'rumah adat' (Wawancara dengan Arifin J. Anat, SH., Ketua Lembaga adat dan Syariah donggo (L ASDO), bertempat di Desa O'o) Pada Tanggal 29 Juli 2019.

Kehidupan masyarakat yang masih natural yang merupakan potensi yang belum banyak diketahui. Beberapa informan kami mengatakan bahwa banyak wisatawan asing yang dating ke wilayah Kecamatan Donggo, meskipun menurut beberapa informan kami di Kecamatan Donggo tidak ada obyek wisata yang menarik, sehingga mereka mencurigai kehadiran para wisatawan tersebut. Sisi pandang dari para Narasumber berbeda dengan sisi pandang para wisatawan asing. Bagi wisatawan asing kehidupan masyarat yang masih natural merupakan daya tarik tersendiri. Sehingga kehidupan masyarakatDonggo yang masih natural ini merupakan potensi wisata yang memiliki nilai jual yang dapat dijadikan sebagai sumber daya peningkatan ekonomi rakyat, apalagi jika didukung dengan penataan land scape sekitar teluk Bima. Donggo selain menarik bagi wisatawan juga menarik bagi ilmuwan asing, hal ini terbukti dengan adanya seorang ilmuwan, Peter Just (2001) yang menulis disertasi dengan judul: Dou Donggo: Conflict and Morality in an Indonesian Society. Bagi para mengambil kebijakan di Donggo khususnya dan di Kabupaten Bima umumnya kurang menyadari akan potensi ekonomi yang sekaligus merupakan competitive advantage yang dimiliki untuk dapat dikembangkan bagi kemakmuran rakyat. Terutama pengembangan industri pariwisata, padahal industri pariwisata merupakan jenis industri yang paling handal dan memiliki banyak keunggulan dibandingkan industri-industri apapun. Produk industri pariwisata tidak pernah "habis dijual", bersifat "quick yielding" juga sebagai "the smokless industry (Yoeti, 1990: 3).

Ketiga potensi ekonomi di atas dapat dikembangkan secara terpadu,

\section{Konflik yang Pernah Terjadi}

\section{Konflik Vertikal}

Masyarakat Donggo pernah melakukan demonstrasi besar-besaran pada tahun 1972 di era Bupati Suharmaji. Para demonstran melakukan demonstrasi di depan Kantor Bupati untuk menuntut pemerataan pembangunan. Namun, karena banyak demonstran yang membawa senjata tajam, sebelum sampai ke Kantor Bupati, rombongan demonstran dihadang oleh petugas keamanan di Kecamatan Woha. Kemudian kepada para demontran Pemerintah Daerah menjanjikan akan melakukan pengaspalan jalan menuju Kecamatan Donggo. Namun janji tersebut tidak pernah direalisasikan. Pengaspalan jalan ke Donggo baru direalisasikan pada tahun 1989 pada waktu H. Hariyanto menjabat sebagai Bupati Bima. Akibat aksi 
tersebut beberapa tokoh Donggo ditahan, mereka adalah: H. Kaho, H. Abdul Majid Bakri, H. M. Ali Tamrin, H. Abbas Oya. BA, dan Jamaluddin Yasin (Wawancara dengan Bapak Makarau, S.Pd.,M.Si dan Bapak Arifin J. Anat, SH., 29 Juli 2019).

\section{Konflik Horisontal}

Pada tahun 1972, Gereja Gema Injil di Kampung engari dibakar massa. Kemudian umat Kristen membangun rumah tinggal di Jango di lingkungan umat Islam dan digunakan sebagai tempat kebaktian. Pada tahun 2000 sebagai imbas dari konflik nasional yang hampir merata di seluruh wilayah Indonesia, di wilayah Kecamatan Donggo juga terjadi konflik horizontal. Gereja Gema Injil di Jango kembali dibakar massa (Wawancara dengan Bapak Makarau, S.Pd.,M.Si dan Bapak Arifin J. Anat, SH., 29 Juli 2019). Kemudian, gereja tersebut dibangun kembali atas bantuan Sony Keraff dan tidak pernah dipermasalahkan hingga sekarang.

\section{Potensi Konflik}

1. Pemanfaatan rumah tinggal sebagai tempat ibadah. Sebagai mana keberadaan rumah tinggal di Jembatan Ndano, yang dimanfaatkan sebagai tempat kebaktian dan sebagai tempat transit truk ekspidisi sembako trans Jawa-Timor. Sebagaian tokoh dan masyarakat Muslim mengacu kepada pengalaman menghawatirkan ditempat tersebut lama kelamaan akan dibangun tempat ibadat yang permanen dan megah, ( Wawancara dengan Bapak Makarau, S.Pd.,M.Si dan Bapak Arifin J. Anat, SH., 29 Juli 2019).

2. Tempat penjualan miras. Di tempat transit truk ekpidisi tersebut disinyalir juga digunakan sebagai tempat penjualan miras. Keberadaan tempat penjualan miras dilingkungan warga Muslim ini sangat meresahkan. Ada kekhawatiran para orang tua di Donggo terhadap anak-anak mereka kalau sampai terjerumus ke dalam kebiasaan Pihak yang berwajib hendaknya belajar dari konflik Poso yang antara lain dipicu karena keberadaan tempat penjualan miras (Syahadat, 2007: 2).
3. Kawin campur (berbeda agama), karena berakibat terjadinya konversi agama. Perkawinan berbeda agama ini tidak dikehendaki oleh undangundang, maka jika ada calon pengantin yang berbeda agama sebelum melaksanakan perkawinan salah satu calon melakukan konversi agama. Sementara perpindahan agama tidak disukai oleh masyarakat Meski sebagian penganut agama mengatakan masalah cinta merupakan urusan pribadi seseorang. Sedangkan kelompok agama yang lain dan berdasarkan adat yang berlaku di Donggo "keluar dari agama" sama dengan "keluar dari keluarga" (Wawancara dengan tokoh 3 kelompok agama ditempat yang berbeda, 16, 17. 18 November 2012).

\section{Kearifan Lokal dan Kerukunan}

a. Masyarakat Donggo sebagai masyarakat patronase masih sangat menghargai petuah orang-orang tua. Penghormatan terhadap orang tua dan orang yang dituakan masih tinggi. Petuah tokoh-tokoh agama dipandang sebagai penyejuk hati masyarakat (Wawancara dengan Bapak Arifin J. Anat, SH. Ketua Lembaga adat LASDO, 30 Juli 2019). Meski belakangan ini ketaatan anakanak muda terhadap orang-orang tua dan yang dituakan mulai luntur.

b. Maja labo dahu' merasa malu dan takut pada perbuatan yang salah merupakan kearifan lokal yang dijadikan motto Kabupaten Bima. Anggota masyarakat di wilayah Donggo dan umumnya Kabupaten Bima memiliki rasa malu untuk melakukan perbuatan yang salah (deviant), sehingga masyarakat di wilayah ini cenderung berperilaku baik sesuai dengan norma-norma dan tatanan adat setempat (Wawancara dengan Arifin J. Anat, Anat, SH. Ketua Lembaga adat LASDO, 30 Juli 2019).

c. Mbolo weki (musyawarah bersama), Jika ada masalah dibicarakan bersama.

d. Tekara nee (sumbang sih), hal ini biasanya dilakukan dalam upacara siklus hidup, hajatan naik haji dan doa syukuran sehabis 
panen atau anak tamat sekolah, semua warga tidak pandang agama berdatangan Revitalisasi Kearifan Lokal Pengembangan Wadah Kerukunan dan Ketahanan Masyarakat Lokal di Kecamatan dan membawa sumbangan, baik berupa uang atau bahan makanan.

e. Masih kuatnya adat, yakni keberadaan Lembaga Adat dan Syariat Dongo (LASDO) yang menangani: (1) konflik tanah; (2) perselingkuhan/ perzinahan; (3) perkelahian pemuda antar kampung (Wawancara dengan Arifin J. Anat, Anat, SH. Ketua Lembaga adat LASDO, 30 Juli 2019), Jika terjadi pelanggaran adat segera diselesaikan secara adat dan konflik pun dapat dihindarkan. Bahkan untuk penyelesaian kasus perselingkuhan (perzinaan) hukum adat masih kuat. Jika ada kasus perselingkuhan, pelakunya dicambuk dan diarak (dibaja) dari Desa Mpili sampai Dori Dungga. Sepanjang jalan pelaku meneriakkan kata-kata "jangan berbuat seperti saya, inilah akibatnya". Setelah selesai pelaksanaan hukuman, jika pelaku perempuan sudah bersuami, suaminya diminta untuk menceraikan. Selanjutnya pelaku perselingkuhan dikawinkan. Jika pelaku perempuan dalam keadaan hamil, ditunggu sampai melahirkan, baru kemudian dikawinkan. Pelaksanaan hukum adat ini didukung oleh pemerintah setempat. Kalau adat yang melakukan sangsi terhadap pelaku tindak kejahatan hingga mengakibatkan kematian tidak ada yang menuntut. Jika ada yang menuntut, ang bersangkutan malah bisa kena sangsi (Wawancara dengan Arifin J. Anat, Anat, SH. Ketua Lembaga adat LASDO, 30 Juli 2019).

Respon Tokoh Agama/Adat terhadap Wadah Kerukunan.

Di Kecamatan Donggo sudah didirikan

Forum kerukunan Umat Beragama (FKUB) tingkat kecamatan pada tahun 2007, dengan susunan pengurus: Ketua: H. Salman, SMHk, Camat Donggo (Muslim); Wakil Ketua: Johanes Jafar (Kristen); Sekretaris Samsuddin (Islam);
Wakil Sekretaris: Andreas Usman (Katolik). Namun kepengurusan FKUB tersebut belum diresmikan (belum ada SK-nya). Latar belakang dibentuknya FKUB tingkat kecamatan tersebut karena adanya kawin campur, yang menimbulkan keresahan masyarakat (Wawancara dengan Arifin J. Anat, Anat, SH. Ketua Lembaga adat LASDO, 30 Juli 2019). Respon tokoh agama/adat terhadap wadah kerukunan sebelum diadakan FGD, secara umum sepakat atas keberadaan wadah kerukunan di Donggo, mereka memandang keberadaan wadah kerukunan sangat perlu, agar antarumat beragama dapat bersilaturrahmi, sehingga keakraban dapat terpelihara dengan baik dan konflik antarumat dapat dihindarkan (Wawancara dengan Ignais Ismail, Kategis Gereja Katolik Kecamatan Donggo, Kepala KUA Kecamatan Donggo, 11 Agustus 2019). Keberadaan wadah kerukunan menjadi sangat penting, terutama jika para pengurus wadah tersebut adalah tokoh-tokoh agama yang disegani oleh masyarakat dan penganut agama masing-masing. Keberadaan wadah kerukunan akan semakin menambah eratnya kerukunan umat beragama. Disamping itu, keberadaan wadah kerukunan di tingkat kecamatan dapat memperlancar arus informasi (deteksi dini) dari munculnya gejala-gejala konflik (Wawancara dengan tokoh adatKecamatan Donggo). Sebelum diadakan FGD yang dipandang sebagai wadah kerukunan oleh para responden adalah FKUB tingkat kecamatan. Respon tokoh agama/adat terhadap wadah kerukunan pada waktu diselenggarakan FGD menegaskan pentingnya keberadaan wadah kerukunan, meski sebagian besar peserta FGD tidak setuju jika wadah kerukunan yang dimaksud adalah FKUB tingkat kecamatan. Mereka justru lebih memilih LASDO sebagai wadah kerukunan dengan catatan dengan revitalisasi dan menjadikan LASDO semakin lebih representatif bagi wadah kerukunan seluruh umat yang ada di Kecamatan Donggo. Dengan demikian diharapkan LASDO juga dapat difungsikan sebagai ketahanan masyarakat lokal Donggo. 


\section{KESIMPULAN}

1. Kerukunan di wilayah Kecamatan Donggo cukup baik. Meski di wilayah ini terdapat tiga kelompok penganut agama tetapi mereka dapat hidup berdampingan secara damai. Konflik yang pernah terjadi berupa:

a) konflik vertikal antara rakyat dan pemerintah pada tahun 1972, masyarakat Donggo menuntut keadilan (pemerataan pembangunan) dengan melakukan demonstrasi besar-besaran; b) Pada tahun 1972 terjadi pembakaran rumah ibadah yang didirikan di lingkungan umat lain; pada tahun 2000, yakni konflik antar umat beragama sebagai imbas dari konflik yang terjadi di tingkat nasional. Di Donggo terjadi pembakaran terhadap rumah ibadah yang pernah dibakar pada tahun 1972.

2. Potensi konflik yang ada di wilayah Kecamatan Donggo yang dapat diidentifikasi antara lain: a) Keberadaan rumah tinggal dan transit truk ekspedisi sebagai tempat kebaktian dan tempat penjualan miras; b) Kawin campur (berbeda agama), karena berakibat terjadinya konversi agama.

3. Kearifan lokal sebagai upaya mempertahankan kerukunan yang dimiliki oleh masyarakat Donggo, antara lain: a) Masyarakat Donggo sebagai masyarakat patronase masih sangat menghargai petuah orangorang tua; b) Maja Labo Dahu, merasa malu dan takut pada perbuatan yang salah; c) Mbolo weki (musyawarah bersama), Jika ada masalah dibicarakan bersama; d) Tekar nee (sumbang sih); e) Masih kuatnya adat (keberadaan LASDO) jika terjadi pelanggaran adat segera diselesaikan secara adat dan konflik pun dapat dihindarkan.

4. FKUB tingkat kecamatan pernah dibentuk namun belum diresmikan. Para tokoh agama/masyarakat (setempat) memberikan respon positif terhadap pengembangan wadah kerukunan. Namun kemudian yang direvitalisasi sebagai wadah kerukunan dan ketahanan local adalah lembaga adat LASDO.

\section{SARAN}

1. Potensi konflik sebagaimana telah teridentifikasi hendaknya dapat diantisipasi, sehingga kondisi kerukunan di Kecamatan Donggo dapat dipelihara dengan baik.

2. Kearifan lokal yang berfungsi sebagai sarana kerukunan dan dapat difungsikan ketahanan masyarakat untuk mengatasi konflik hendaknya dapat terus dijaga kelestariannya baik oleh masyarakat sendiri maupun aparat.

3. Keberadaan LASDO setelah direvitalisasi hendaknya dapat dijadikan sebagai stimulator bagi pengembangan wadah kerukunan beragama dan ketahanan lokal. Untuk mewujudkan kerukunan dapat dilakukan dengan mengalihkan perhatian masyarakat misalnya, pada kegiatan gotong-royong Revitalisasi Kearifan Lokal Pengembangan Wadah Kerukunan dan Ketahanan Masyarakat Lokal di Kecamatan. pengembangan bidang ekonomi dan pelestarian alam, penghijaun secara terpadu di pedesaan dengan pohon buah-buahan di perkotaan (sepanjang pantai teluk Bima dengan bunga flamboyan - dengan semakin hijaunya wilayah Donggo diharapan dapat meningkatkan produk lebah madu dan susu kuda liar. Demikian pula dengan semakin indahnya teluk Bima dengan bunga flamboyant akan dapat meningkatkan kecintaan warga Donggo terhadap daerahnya dan meningkatkan pengembangan industri pariwisata yang akhirnya akan bermuara kepada kesejahteraan masyarakat. Dengan mengalihkan perhatian masyarakat pada kengembangan ekonomi diharapkan ketegangan hubungan antarumat beragama akan terlupakan sehingga tidak akan pernah terjadi lagi konflik-konflik seperti dahulu.

\section{DAFTAR PUSTAKA}

Khamenei, I.A. (2005). Perang kebudayaan. Jakarta. Cahaya.

Kustini, "Kajian Tentang Revitalisasi Wadah erukunan Umat Beragama di Provinsi Bali, Studi Perkembangan FKUB Kecamatan Buleleng, Kabupaten 
Buleleng", dalam Tim Peneliti Puslitbang Kehidupan Keagamaan,

Marzali, Amri, Kearifan Budaya Lokal dan Kerukunan Bearagama, (makalah t.t.). Jakarta: 25 Agustus 2005.

Meleong L.J. (2004). Metodologi Penelitian Kualitatif. Jakarta: Rineka Cipta

Orient. (1999). Kerajaan Bima Jakarta: Yayasaan Obor Indonesia ecole francaise d'Extreme

Rahman, M. Fachrir, Drs. H. MA., dan Nur ukminah, Nika Mbojo Antara Islam dan Tradisi. Mataram: Alam Tara Learning Institute, 2011.

Rahman, M. Fachrir, Drs. H. MA., Islam di Bima: Kajian Historis Islamisasi Era Kesultanan.Mataram: Alam Tara Learning Institute, 2011.

Sugiyono. (2005). Metode Penelitian Kualitatif dan $R \& D$. Bandung: Alfabeta.

Syahadat, A. Malik, Drs. , Poso Kemarin, Hari Ini dan Esok, (makalah t.t.). Poso: 2007.

Wadah Kerukunan Antar Umat Beragama di Berbagai Daerah. Jakarta: Departemen Agama RI Badan Litbang dan Diklat, 2007.

Yoeti, Oka A., Pengantar Ilmu Pariwisata. Bandung: Angkasa, 1990. 